logos_i_ethos_2015_1_(38), s. 41-57

DOI: http://dx.doi.org/10.15633/lie.1044

Karol Jasiński

Uniwersytet Warmińsko-Mazurski w Olsztynie

\title{
Zło brakiem dobra człowieka. Egzystencjalna koncepcja Martina Bubera
}

Jedno z pierwszych egzystencjalnych pytań człowieka dotyczyło tego, skąd wzięło się na świecie zło. Pytanie to pojawiło się między innymi w kontekście doświadczenia różnych katastrof, nieszczęść, cho-

Karol Jasiński - prezbiter archidiecezji warmińskiej; doktor nauk humanistycznych w zakresie filozofii; pracownik Wydziału Teologii Uniwersytetu Warmińsko-Mazurskiego w Olsztynie; główne obszary zainteresowań: filozofia religii i filozofia społeczna. rób, cierpień, czy też krzywd doznanych ze strony innych ludzi. Wszystkie te fenomeny rozumiano jako różne przejawy zła, które może mieć charakter naturalny (związany z przygodną i ułomną naturą świata materialnego) lub moralny (będący wynikiem wolnych czynów osoby ludzkiej). W dziejach myśli ludzkiej podjęto ponadto próbę określenia natury zła, której wynikiem jest pojęcie zła jako braku należnego danemu bytowi dobra.

Należy jednak zauważyć, że problem istnienia, pochodzenia i natury zła nie doczekał się dotąd ostatecznego rozwiązania. Był on podejmowany niejednokrotnie także $\mathrm{w}$ czasach współczesnych. Jednym $\mathrm{z}$ tych myślicieli, którzy zajęli się nim na nowo, był Martin Buber (zm. 1965). Jako Żyd doświadczył on bardzo boleśnie całego ogromu niegodziwości i zła, które były udziałem między innymi jego narodu w wieku XX. Mając na względzie owe traumatyczne przeżycia historyczne, skoncentrował się on w swoich analizach na złu moralnym. Także dla Bubera zło jest pewnym brakiem dobra. Interpretuje on jednak oba pojęcia w świetle uprawianej przez siebie filozofii egzystencjalnej, w kontekście której zło polegałoby przede wszystkim na braku właściwego ukierunkowania życia osoby ludzkiej. 
Poniższe rozważania są próbą prezentacji nieznanej bliżej Buberowskiej koncepcji zła i związanego z nią pojęcia dobra. Zostały one przeprowadzone na podstawie analizy głównych prac żydowskiego filozofa, ze szczególnym uwzględnieniem zasadniczego dla tej problematyki dzieła pt. Bilder von Gut und Böse. Pomoc w odpowiedzi na pytanie dotyczące pochodzenia i natury zła czerpie Buber przede wszystkim z mitologii biblijnej oraz perskiej, na której przesłaniu opiera się jego myśl filozoficzna. Podejście takie wyznacza tym samym tok rozważań. Po ogólnym zarysie Buberowskiej koncepcji mitu zostaną przedstawione główne idee dotyczące zła i dobra, wyłuskane przez żydowskiego filozofa $\mathrm{z}$ biblijnych i perskich obrazów mitycznych. Dopiero na tym tle będzie ukazane filozoficzne ujęcie interesującego nas zagadnienia.

\section{Mit jako wyraz ludzkiego doświadczenia}

W roku 1904, po obronie dysertacji doktorskiej z filozofii, Buber podjął gruntowne badania różnych tradycji mistycznych, m.in. chasydyzmu. Zajęcie to stało się dla niego okazją nie tylko do ponownego postawienia pytań dotyczących podstawowych kwestii ludzkiego życia, które zostały wyrugowane z powszechnej świadomości, chociażby w wyniku silnych tendencji racjonalistycznych i scjentystycznych ${ }^{1}$. Dzięki owym badaniom odkrył on także bogactwo i aktualność treści niektórych zapomnianych już gatunków literackich, np. mitu. Mit stanowił dla niego formę świadectwa dotyczącego spotkania z Absolutem, dzięki któremu człowiek mógł dotrzeć do głębszego sensu rzeczywistości². Ponadto był on opowiadaniem o konkretnym wydarzeniu w świecie naturalnym, które posiadało także cechy nadnaturalne ${ }^{3}$. Jak podkreśla Ch. Schütz,

1 Por. E. Luz, Buber's hermeneutics: The road to the revival of the collective memory and religions faith, "Modern Judaism" 1995 nr 1, s. 82.

Por. M. Buber, Die chassidische Botschaft, [w:] tegoż, Werke. Dritter Band. Schriften zum Chassidismus, München-Heidelberg 1963, s. 829, 838; tenże, Die Lehre vom Tao, [w:] tegoż, Werke. Erster Band. Schriften zur Philosophie, München-Heidelberg 1962, s. 1026-1027; M. Friedman, Martin Buber. The life of dialogue, Chicago 1955, s. 229.

Por. M. Buber, On Judaism, New York 1967, s. 95. 
w micie miała być zdaniem Bubera przechowywana i przekazywana następnym pokoleniom pamięć o pewnych wydarzeniach, które rozegrały się na „początku”. Warto przy tym zauważyć, że ów „początek” posiadał wymiar ponadhistoryczny, tzn. niemożliwy do przeminięcia i niedający się podporządkować żadnemu konkretnemu momentowi dziejowemu4

$\mathrm{Na}$ inną jeszcze kwestię zwraca uwagę Oliver Roy. Otóż mit stanowił dla Bubera nie tylko źródło i pierwotną formę religijności, lecz także narzędzie w odkryciu prawdy egzystencjalnej, odnoszącej się do tych wymiarów życia, których nie można opisać w kategoriach nauki. Prawda ta nie miała więc w pierwszym rzędzie charakteru poznawczego, ale dotyczyła egzystencjalnych przeżyć człowieka ${ }^{5}$. Doświadczenie życiowe, które dochodziło w niej do głosu, było także istotnym elementem mitu, który z niego wyrastał, i przez nie mógł być wyjaśnio$n y^{6}$. Odwołanie się mitu do bezpośredniego doświadczenia człowieka stanowiło o jego prawdzie lub fałszu. Prawdziwy mit dotyczył poszukiwań istoty ludzkiej, badającej głębie własnej egzystencji. Dzięki temu badaniu człowiek mógł odkryć nowe warstwy swojej jaźni i dojść do rzeczywistości, będącej źródłem przeżyć opisywanych w mitach. Miarą prawdy mitu był autentyzm owego doświadczenia egzystencjalnego $^{7}$. W doświadczeniu tym manifestowała się ponadto tajemnica ludzkiego bytu, którą następnie można było wyrazić w rozmaitych narracjach symbolicznych ${ }^{8}$.

Prawdziwe mity były więc rezultatem realnych ludzkich przeżyć. Niekiedy jednak traciły owo konkretne odniesienie i stawały się wyłącznie

4 Por. Ch. Schütz, Verborgenheit Gottes. Martin Bubers Werk - Eine Gesamtdarstellung, Zürich-Einsiedeln-Köln 1975, s. 448.

Por. O. Roy, Martin Buber. Der Wanderer und der Weg, Heildelberg 1968, s. 23, 27.

6 Por. M. Buber, Bilder von Gut und Böse, [w:] tegoż, Werke. Erster Band. Schriften zur Philosophie, München-Heidelberg 1962, s. 635; R. Moser, Gotteserfahrung bei Martin Buber. Eine theologische Untersuchung, Heidelberg 1979, s. 75.

Por. O. Roy, Martin Buber. Der Wanderer und der Weg, dz. cyt., s. 29, 47.

8 Por. Por. E. Luz, Buber's hermeneutics: The road to the revival of the collective memory and religions faith, dz. cyt., s. 73-74. 
symbolicznym wyrazem powszechnego doświadczenia ludzkości. Do nich właśnie można zaliczyć przekazy o początkach zła9.

Trzeba od razu podkreślić, iż dobro i zło nie są dla Bubera jakimiś abstrakcyjnymi wartościami etycznymi, ujmowanymi w ramach hierarchii ${ }^{10}$. Jego zdaniem, człowiek wie o dobru i złu na podstawie własnego doświadczenia wewnętrznego, a narzędziem ich poznania jest introspekcja, do której zdolni są wyłącznie ludzie ${ }^{11}$. Dobro i zło są więc fenomenami antropologicznymi. Nie tworzą obiektywnych struktur lub jakości świata, lecz stanowią pewien typ przeżyć i doświadczeń człowieka ${ }^{12}$.

Warto podkreślić, że Buber odwołuje się w opisie owych fenomenów do ważnego rozróżnienia występującego w języku niemieckim pomiędzy dwoma słowami „übel” i „böse”, które służą do określenia zła. Pierwsze z tych pojęć odnosi się do przedmiotu i opisuje pewną jego cechę. Drugie natomiast dotyczy podmiotu i wskazuje przede wszystkim na jego zamiary, a wtórnie na czyny ${ }^{13}$. Podział ów odpowiadałby te$\mathrm{mu}$, co w tradycyjnej terminologii określało się mianem zła naturalnego („übel”) i moralnego („,böse”). O pierwszym rodzaju zła Buber jedynie niekiedy wspomina. Ma ono dla niego charakter jakiegoś braku w stworzeniu. Rozumie je jako przygodność wszystkich rzeczy i wiąże z kabalistyczną teorią rozbitych naczyń (najniższa forma bytu) ${ }^{14}$. Kiedy mówi natomiast o problemie zła, to ma na uwadze drugą jego formę. Mogą za tym przemawiać pewne aluzje czynione przez żydowskiego myśliciela. Odwołuje się on do biblijnego symbolu zła - Goga, który tylko dlatego jest obecny na zewnątrz, że występuje przede wszystkim w naszym

9 Por. M. Friedman, Martin Buber. The life of dialogue, dz. cyt., s. 234.

10 Por. M. Buber, Bilder von Gut und Böse, dz. cyt., s. 650.

11 Por. tamże, s. 621, 635; M. Buber, Gog und Magog. Eine Chronik, [w:] tegoż, Werke. Dritter Band. Schriften zum Chassidismus, München-Heidelberg 1963, s. 1046.

12 Por. A. Edmaier, Dialogische Ethik. Perspektiven - Prinzipien, Kevelaer 1969, s. 81-82.

13 Por. P. Häberlin, Das Böse. Ursprung und Bedeutung, Bern 1960, s. 5, 7-8, 13; K. Löwith, Der philosophische Begriff des Besten und Bösen, [w:] Das Böse, mit Beiträgen von M.-L. von Franz, L. Frey-Rohn, K. Kerenyi, K. Löwith, V. Maag, M. Schlappner, K. Schmid, G. Widengren, Zürich-Stuttgart 1961, s. 211-212, 220.

14 Por. M. Buber, Die chassidische Botschaft, dz. cyt., s. 748-750, 796. 
wnętrzu ${ }^{15}$. W innym miejscu zauważa, iż w człowieka został wszczepiony „zły popęd”, który pochodzi od boskiej zasady i jest źródłem chaosu w świecie oraz upadku ${ }^{16}$.

\section{W kręgu mitów biblijnych}

Opis doświadczenia zła, jak wspomniano już wyżej, zawierają mity, które są wyrazem doświadczenia ludzkości ${ }^{17}$. Po nie sięgnął także Buber w swoim małym dziełku pt. Bilder von Gut und Böse. Swoje rozważania rozpoczyna od analizy biblijnego podania o rajskim drzewie poznania. Człowiek zdobył przy nim wiedzę o dobru i złu na wzór Boga. Co znaczyło owo poznanie dobra i zła? Buber rozważał różne możliwości: zdobycie pożądania płciowego, świadomości moralnej czy też osiągnięcie ogólnej znajomości świata. Odrzuca jednak wszystkie te hipotezy. Pierwszą z tej racji, że Bóg jest ponadpłciowy, a człowiek od początku został stworzony jako istota płciowa. Kolejną z tej racji, że świadomość moralna stanowiłaby wówczas przeszkodę $\mathrm{w}$ zdobyciu życia wiecznego, co wydaje się być absurdalne. Na rzecz ostatniej hipotezy nie ma natomiast żadnych przesłanek w Biblii: człowiek musi posiadać wiedzę o świecie, skoro tkwi w nim tchnienie Boga. Ostatecznie dochodzi Buber do wniosku, iż „poznanie dobra i zła” oznacza uświadomienie sobie ukrytych w bycie przeciwieństw. Występuje jednak zasadnicza różnica między Stwórcą a człowiekiem. Pierwszy z nich może je ogarniać i panować nad nimi, dla drugiego jest to niemożliwe. Człowiek wkracza więc w egzystencjalną sytuację znaczoną przeciwieństwami. Poznaje je zwłaszcza wtedy, gdy wykroczy przeciw Bogu ${ }^{18}$.

Według Roya Buber z pewną ironią odczytał mit o Adamie i Ewie, którzy chcieli spróbować być niczym Bóg w poznaniu dobra i zła. Nie mogli pogodzić się z tym, że ich wiedza jest inna niż wiedza Boga, co

15 Por. tenże, Gog und Magog, dz. cyt., s. 1043.

16 Por. tamże, s. 1035.

17 Por. M. Friedman, Martin Buber. The Life of Dialogue, dz. cyt., s. 105.

18 Por. M. Buber, Bilder von Gut und Böse, dz. cyt., s. 612-617; tenże, Zwei Glaubensweisen, [w:] tegoż, Werke. Erster Band. Schriften zur Philosophie, München-Heidelberg 1962, s. 766. 
doprowadziło w konsekwencji do załamania komunikacji bosko-ludzkiej. Od tej pory człowiek, spotykając słowo Boga, ucieka od niego. Nie obiera jednak określonego kierunku, ale dąży raczej do samounicestwienia. Owe bezdroża współczesnego Adama pokazuje żydowski filozof na przykładach różnych myślicieli w innym swoim dziele pt. Das Problem des Menschen ${ }^{19}$. Widać w nim, że zniszczony dialog człowieka z Bogiem został zastąpiony przez rozmowę $\mathrm{z}$ sobą lub zatopienie się $\mathrm{w}$ anonimowej społeczności, w której brakuje dialogu między ludźmi ${ }^{20}$.

Buber podejmuje też analizę opowiadania o Kainie i Ablu, w którym jest mowa o tym, że Bóg prowadzi rozmowę z Kainem. Stwórca dostrzega u niego brak dobrych intencji, czego rezultatem jest posiadanie „ponurego oblicza”. Na człowieka będącego w takim stanie czeka zło (grzech), oznaczające demona pragnącego zawładnąć duszą, która nie jest w stanie nad nim zapanować. Buber wysuwa tu wnioski, które będą istotne dla jego koncepcji dobra i zła. Otóż Bóg wzywa człowieka, aby wybierał dobro, czyli kierunek na Niego. Istota ludzka nie zawsze odpowiada na to wezwanie. Niejednokrotnie, zamiast skierować się ku Bogu, wystawia się na przeciwstawności życia ${ }^{21}$. Sytuacja taka miała miejsce także w przypadku Kaina, doświadczającego stanu wewnętrznego rozbicia. Nie potrafił on ukierunkować właściwie swojej egzystencji i w ten sposób także uporządkować swoje postępowanie, dlatego pogrążył się w chaosie możliwości, które nim zawładnęły 22 .

Trzeci mit biblijny omawiany przez Bubera to historia potopu. Ważne dla jej zrozumienia są dwa zdania wyjęte $\mathrm{z}$ Księgi Rodzaju mówiące o „złych obrazach ludzkiego serca”. Te obrazy to nasze wyobrażenia, odnoszące się do możliwości, które przed nami stoją. Operowanie wyobrażeniami jest grą możliwościami. Człowiek sięga po nie i niektóre z nich zaczyna ucieleśniać, ale to go deprawuje, ponieważ znaczone jest samowolą. Po potopie, zdaniem Bubera, Bóg daje do zrozumienia, iż są także

19 Por. O. Roy, Martin Buber. Der Wanderer und der Weg, dz. cyt., s. 33, 41-42.

20 Por. A. Edmaier, Dialogische Ethik. Perspektiven - Prinzipien, dz. cyt., s. 85.

${ }_{21}$ Por. M. Buber, Bilder von Gut und Böse, dz. cyt., s. 619-621.

22 Por. M. Friedman, Martin Buber's New View of Evil, "Judaism” 1953 nr 2/3, s. 242. 
dobre wyobrażenia, które pomagają zwrócić się ku Bogu i uporządkować chaos możliwości. Na kanwie nauki o dobrych i złych wyobrażeniach powstała talmudyczna koncepcja „dobrego" i „złego” popędu. Oba są równie niezbędne w życiu człowieka, a jego zadaniem jest ich zjednoczenie. Popęd zły oznacza prowadzący na manowce dynamizm człowieka. Popęd dobry natomiast ukierunkowanie życia. Celem człowieka jest zjednoczenie obu popędów, czyli nadanie kierunku swoim namiętnościom ${ }^{23}$.

Motyw podziału i napięcia w duszy, obecny w myśli Bubera, jest świadectwem wpływu na niego nie tylko Biblii, ale również mistycznej tradycji judaizmu (chasydyzmu) ${ }^{24}$. Pomocą służyły mu także pisma Fiodora Dostojewskiego, dzięki którym Buber znalazł obszerne analizy dynamizmu życiowego oraz głęboki wgląd w wewnętrzne pęknięcie w człowieku ${ }^{25}$.

Myśl o istotowej polaryzacji bytu ludzkiego potwierdza on w rozmowie z Carlem Rogersem. Kiedy ten pyta go o naturę ludzką, czyli o to, co odsłania się w momencie wchodzenia w głąb osoby, Buber odpowiada, że kiedy zbliża się do osoby, doświadcza jej przede wszystkim jako rzeczywistości spolaryzowanej. Głębsze i szersze poznanie człowieka polega na dostrzeżeniu, że to, co w nim najlepsze, jest zawsze powiązane z tym, co najgorsze. Ciągle na nowo powstaje polaryzacja, której biegunami są przyjęcie czegoś i odmowa. Można jednak dążyć do zaprowadzenia porządku, nadania kształtu, ukierunkowania. Dobro nie jest substancją, lecz kierunkiem ${ }^{26}$. Polaryzację ujmuje Buber więc nie jako kategorię myślenia lub poznania, ale jako podstawową daną antropologiczną. Istota ludzka żyje, doświadczając rozbicia swego „Ja", które przybiera różne formy: różnic między przedmiotami, przeciwieństw poznania, wykluczających się postaw, otwartości i zamknięcia świata na $\mathrm{Boga}^{27}$. Wszystkie

23 Por. M. Buber, Bilder von Gut und Böse, dz. cyt., s. 622-626.

24 Por. tenże, Drei Reden über das Judentum, Frankfurt a.M. 1920, s. 37-41.

25 Por. M. Friedman, Martin Buber. The life of dialogue, dz. cyt., s. 35.

26 Por. C. Rogers, Aneks (Dyskusja: C. Rogers, M. Buber), „Znak” 1968 nr 11/12, s. 1535-1536.

27 Por. M. Buber, Bilder von Gut und Böse, dz. cyt., s. 607; tenże, Die chassidische Botschaft, dz. cyt., s. 750; tenże, Gottesfinsternis, [w:] tegoż, Werke. Erster Band. Schriften zur Philosophie, München-Heidelberg 1962, s. 597; tenże, Ich und Du, [w:] tegoż, Werke. Erster Band. Schriften zur Philosophie, München-Heidelberg 1962, s. 79, 85, 96, 122, 152; tenże, Urdistanz und Beziehung, [w:] tegoż, Werke. Erster Band. Schriften zur Philosophie, München-Heidelberg 1962, 
formy przeciwieństw mają swoją podstawę w bytowej podstawie świata (Tajemnicy), która sama ukazuje się jako pełna paradoksów ${ }^{28}$. Człowiek nie jest jednak wydany na pastwę takiego stanu, ale może go przezwyciężyć. Jedynym możliwym tego sposobem jest włączenie wszystkich przeciwieństw w relację absolutną z Bogiem, z którym mamy do czynienia w każdorazowym spotkaniu $\mathrm{z}$ konkretnymi bytami ${ }^{29}$.

\section{Przesłanie mitów perskich}

Po omówieniu mitów biblijnych twórca filozofii dialogu sięga także do staroperskiej Awesty. W tamtejszych mowach Zaratustry odnajduje motyw mówiący o dwóch zasadach bytu: dobrej i złej. Wywodziły się one ze wspólnego praciała lub, jak to określono na innym miejscu, z najwyższego boga Ahura Mazdy (Mądry Pan), który je ogarniał. Chcąc pokonać zło, najpierw się go wyzbył, a następnie zaczął z nim walczyć. Do walki tej został włączony następnie człowiek. Powierzono mu władzę dokonywania samodzielnego wyboru, za pomocą której musi oddzielać prawdę od pozoru. Człowiek na wzór Boga nosi dobro i zło w sobie. Musi się on opowiedzieć po jednej lub po drugiej stronie, a tym samym określić siebie jako dobrego lub złego. W micie tym pojawił się jednak inny problem: skąd w bogu mogło istnieć zło? Odpowiedzi na to pytanie udziela opowieść o bezgranicznym czasie Zerwanie. Składał on ofiary, aby otrzymać syna, Ahura Mazdę. Nie pomogły one jednak, co przyczyniło się do powstania wątpliwości dotyczących sensowności ich składania. Wówczas w jego ciele pojawił się dobry duch z ofiary i zły duch z wątpliwości. Zło rodzi się więc z wątpienia jako braku decyzji. $\mathrm{W}$ innym jeszcze miejscu Awesty wyrażona jest myśl, że dobro czynimy świadomie, a zło nieświadomie ${ }^{30}$.

s. 416; J. Speck, Martin Buber: Die Aporie des Dialogischen, [w:] Grundprobleme der grossen Philosophen. Philosophie der Gegenwart IV (Weber, Buber, Horkheimer, Adorno, Marcuse, Habermas), Hrsg. J. Speck, Göttingen 1981, s. 84.

\footnotetext{
28 Por. M. Buber, Ich und Du, dz. cyt., s. 146.

29 Por. tamże, s. 129, 132, 146.

30 Por. M. Buber, Bilder von Gut und Böse, dz. cyt., s. 627-630.
} 
Buber analizuje też irańskie podanie o królu Jima (Jama), którego bóg Ahura Mazda wezwał do strzeżenia jego religii, a następnie do ochrony świata, wolnego od niszczycielskich mocy, choroby i śmierci, o co zresztą prosił on bogów. W pewnym momencie Ahura Mazda poinformował go, że świat doświadczy czegoś na wzór potopu. Pouczono go, aby zbudował twierdzę i ukrył w niej nasienie najlepszych istot żyjących. On jednak oprócz tego wpuścił do niej także demoniczność. Jednocześnie zaczął w swych myślach wychwalać siebie za to, co uczynił. Skutkiem tego stał się śmiertelny. Wina jego, która zadecydowała o jego losie, polegała $\mathrm{w}$ tym przypadku na kłamstwie, ale nie słownym, lecz egzystencjalnym, ponieważ zaczął wszystko sobie przypisywać i siebie uważał nawet za stwórcę. W ten sposób sprzeniewierzył się sobie i bogom. Prawda polegałaby tu więc na potwierdzeniu bytu we własnej egzystencji, a kłamstwo na dokonującym się w duszy udawaniu, które znajduje następnie swój wyraz w relacji do innych. Dokonując wyboru między tymi dwoma sposobami życia, człowiek miałby wpływ na wynik walki kosmicznej, która toczy się w świecie. Bycie prawdziwym oznaczałoby wówczas wzmacnianie bytu, natomiast bycie fałszywym - osłabianie go i upadek ${ }^{31}$. Kłamstwo zachodzi więc nie na płaszczyźnie mowy lub czynu, lecz bytu ${ }^{32}$. Buber akceptuje tę myśl, która znajduje także potwierdzenie w myśli św. Augustyna z Hippony, podkreślającego, że prawda ludzka jest potwierdzona przez bycie prawdziwym ${ }^{33}$.

\section{Filozoficzna interpretacja mitów}

Na bazie powyższych tekstów Buber stara się sformułować własną koncepcję zła i dobra. Istotne dla tej koncepcji są dwa pojęcia: możliwość i kierunek ${ }^{34}$. Pierwszym stadium życia człowieka jest doświadczenie

31 Por. tamże, s. 631-634.

32 Por. M. Buber, Die chassidische Botschaft, dz. cyt., s. 764.

33 Por. K. Dzikowska, Obecność i moc. Zagadnienie prawdy w pismach Martin Bubera, „Filozofia Dialogu” 2003 nr 1, s. 131; A. Edmaier, Dialogische Ethik. Perspektiven - Prinzipien, dz. cyt., s. 83 .

Por. M. Buber, Bilder von Gut und Böse, dz. cyt., s. 607, 636, 639. 
chaosu dostrzeganego w duszy, które było udziałem bohaterów biblijnych. Wiąże się to z tym, że człowiek żyje nie tylko w świecie aktualnym, lecz także $\mathrm{w}$ świecie możliwości. Istota ludzka uświadamia sobie właśnie owo przebywanie w świecie możliwości, gdy pochłania go pełna obrazów fantazja. Niesie to ze sobą zagrożenie. Chaos możliwości staje się chaosem różnych sposobów bycia i postępowania. Cechą tego stanu jest brak kierunku. Stan taki prowadzi do wytworzenia się w człowieku napięcia, którego nie może wytrzymać. Zaczyna więc korzystać z rzeczy, do której przypadkowo przywiodła go namiętność. Może on jednak podjąć wysiłek integracji siebie. Zaczyna wówczas wyczuwać jakiś kierunek. Jak zaznacza filozof z Heppenheim, kierunek w sensie ścisłym jest tylko jeden, ale na tym etapie człowiek nie ma takiej świadomości. Nadal znajduje się między ukierunkowaniem siebie a pokusą igrania możliwościami. Na tym tle Buber definiuje zło: „Zło jest brakiem kierunku i - wynikającym stąd - chwytaniem, łapaniem, uwodzeniem, zmuszaniem, wykorzystywaniem, naginaniem, dręczeniem, niszczeniem tego, co się przydarza. Dobro jest kierunkiem i tym, co się w tym kierunku czyni; co zaś się w nim czyni, jest czynione całą duszą, tak, iż do czynu wchodzi wszelka siła i namiętność, z którą mogłoby być czynione zło"35.

Buber podkreśla tu bardzo mocno dwie zasadnicze kwestie. Po pierwsze, zła nie można wykonać całą duszą. Gdy człowiek zamierza uczynić jakieś zło, wówczas spostrzega w sobie coś, co go niepokoi. Jest to delikatny protest duszy, na który ludzie często nie zważają, ponieważ zdążyli się do niego przyzwyczaić3 ${ }^{36}$. Po wtóre, według Bubera nie ma „zła jako takiego", stanowi ono jedynie warunek życia ludzkiego i postawę w życiu jednostki. Zło w formie warunku poprzedzałoby ukierunkowanie ludzkiego życia, a jako postawa polegałoby na samoafirmacji istoty ludzkiej.

35 Tamże, s. 640-643.

36 Por. Philosophical interrogations, ed. S. i B. Rome, New York 1964, s. 112-113. Pojawia się tu problem, dlaczego zły uczynek nie może przyczyniać się do naszej samorealizacji oraz dlaczego nie można całym swoim bytem robić złych rzeczy? Na te pytania Buber nie udziela jednak odpowiedzi. Por. M. Fox, Einige Probleme in Bubers Moralphilosophie, [w:] Martin Buber, Hrsg. P. A. Schilpp, M. Friedman, Stuttgart 1963, s. 149-150. 
Z tej racji żaden człowiek nie jest po prostu zły, ponieważ może ukierunkować swoje siły i nikt nie jest po prostu dobry, ponieważ nie jest wolny od wewnętrznych napięć. Człowiek jest więc z natury swej dwojaki: „,dobry-i-zły"37. Zdaniem Arna Anzenbachera podkreślanie przez Bubera, że zło jest warunkiem dobra, miało na celu dowartościowanie roli namiętności jako sił napędowych ludzkiego postępowania. Z jednej strony popychają one bowiem człowieka do czynu, z drugiej zaś umożliwiają wejście w dialog, przyczyniając się do jego rozwoju ${ }^{38}$.

Tak więc najpierw człowiek doświadcza zła jako niezdecydowania. Istota ludzka podaje wówczas w wątpliwość samą siebie, ponieważ jej samowiedza nie pozwala na autoafirmację. Stan ten albo się pogłębia, albo prowadzi do podjęcia decyzji ukierunkowującej jego życie. Człowiek jest bowiem istotą potrzebującą potwierdzenia $\mathrm{z}$ tej racji, że żyje zagubiony w wirze różnorakich możliwości. Może ono dokonać się z zewnątrz (dzięki innym ludziom), ale to nie wystarcza, gdy brakuje wewnętrznej afirmacji w wyniku odrzucania siebie. Każda istota ludzka musi przede wszystkim potwierdzić siebie taką, jaką jest. Na to właściwie zwracają uwagę mity irańskie, gdy mówią o prawdziwym i zakłamanym bycie ${ }^{39}$.

W drugim stadium zło polega na afirmacji przez osobę jej własnego rozdarcia. Człowiek, jako byt potrzebujący potwierdzenia, dokonuje wyboru, którego brakuje w stanie pierwszym. Zło ulega wówczas radykalizacji (substancjalizacji) ${ }^{40}$.

W Zwei Glaubensweisen (Dwóch typach wiary) Buber mówi nie tyle o zatwardziałości samego człowieka $\mathrm{w}$ drugim stadium zła, ile

37 Por. Philosophical interrogations, dz. cyt., s. 114.

38 Por. A. Anzenbacher, Die Philosophie Martin Bubers, Wien 1965, s. 79.

39 Por. M. Buber, Bilder von Gut und Böse, dz. cyt., s. 644-647.

40 Por. tamże, s. 648. Drugi poziom dotyczy zła radykalnego, które można orzec tylko w perspektywie Boga. Buber nie chce używać określenia „absolutne“, ponieważ wskazywałoby ono na istnienie drugiej siły w świecie obok Boga. Ponadto nie zawsze „zło relatywne“ pierwszego poziomu musi zakładać istnienie „zła absolutnego“. Por. M. Buber, Die Frage an den Einzelnen, [w:] tegoż, Werke. Erster Band. Schriften zur Philosophie, München-Heidelberg 1962, s. 258-259; Philosophical interrogations, dz. cyt., s. 110-111; E. Brinkschmidt, Martin Buber und Karl Barth. Theologie zwischen Dialogik und Dialektik, Neukirchen 2000, s. 110. 
o zatwardziałości serca ludzkiego sprawianej przez Boga. Nie jest ona do końca dostępna ludzkiemu rozumieniu. Można przypuszczać, że człowiek ma w niej jakiś swój udział dzięki swej wolności i odpowiedzialności. Stanowi ona rezultat absolutnej samoafirmacji, przez którą grzesznik zamyka się na Boga i Jego wskazania. Zatwardziałość jest więc wynikiem sprzeciwu człowieka wobec Boga ${ }^{41}$.

Zło jest zatem, po pierwsze, brakiem decyzji. Po wtóre, jest ono decyzją błędną, nie-ukierunkowaną na „Ty” boskie. Z tego można by wyciągnąć wniosek, że zło jest ostatecznie tylko pewnym subiektywnym stanem osób, ściśle związanym z wymiarem ich wolności i ze sferą podejmowanych decyzji. Tak jednak nie jest ${ }^{42}$. Tym więc, co określałoby w sposób istotny człowieka u Bubera, byłaby decyzja. Człowiek jest bytem podejmującym decyzję, która odsyła nas do innych ${ }^{43}$. Niekiedy podkreśla się słusznie, że zło nie jest tylko subiektywnym stanem braku decyzji i czynem wypływającym z przyzwolenia na ten brak, lecz że jest ono także obiektywną krzywdą tego bytu, z którym człowiek winien być w relacji dialogu. Pomniejszając innego, człowiek traci również sam na wartości ${ }^{44}$.

W koncepcji Bubera ludzkie zło może być traktowane także jako odmowa. Człowiek jest stale wzywany przez potencjalne „Ty” do opuszczenia siebie (jako obiektu poznania lub funkcjonalnego podmiotu) oraz świata. Są dwie okazje, aby opuścić ten stan: tęsknota za potwierdzeniem siebie jako bytu unikalnego (możliwe tylko w relacji dialogicznej) oraz wezwanie idące od innej osoby. Istota ludzka może jednak nie skorzystać z tych okazji ${ }^{45}$.

${ }_{41}$ Por. M. Buber, Zwei Glaubensweisen, [w:] tegoż, Werke. Erster Band. Schriften zur Philosophie, München-Heidelberg 1962, s. 712-716.

42 Por. L. Zeigler, Personal Existence: A Study of Buber and Kierkegaard, „The Journal of Religion" [dalej: JR] 1960 nr 2, s. 86.

43 Por. W. P. Glinkowski, Jedyny czy Pojedynczy? Martin Buber wobec koncepcji antropologicznych Kierkegaarda i Stirnera, „Edukacja Filozoficzna” 2005 nr 40, s. 184.

44 Por. L. D. Streiker, The promise of Buber. Desulatory Philippics and Irenic affirmations, Philadelphia-New York 1969, s. 73.

45 Por. R. S. Smith, Mourning becomes existence: Martin Buber's "melancholy" ontology, JR, 1989 nr 3, s. 337-338. 
Dobro natomiast, w przeciwieństwie do zła, polega na właściwym ukierunkowaniu naszego życia. Trzeba przy tym zauważyć, iż pojęcie „kierunku” przechodziło u Bubera pewną ewolucję. Początkowo rozumiał je jako wrodzoną człowiekowi siłę, którą ma on sobie uświadomić i z siebie wydobywać. $Z$ czasem takie podejście zostaje odrzucone na rzecz podejścia dialogicznego, zgodnie z którym człowiek otrzymuje kierunek poprzez otwarcie się na inny byt całą swoją istotą ${ }^{46}$.

Buber podkreśla jednak, że tak naprawdę jest tylko jeden właściwy kierunek w przypadku decyzji podejmowanej całą duszą, ale może on być rozumiany dwojako: albo ku osobie, albo ku Bogu. Kierunek ów związany jest w pierwszym rzędzie z konkretną osobą, która jest jedyna w swoim rodzaju. Sprawcą tej wyjątkowości jest Stwórca, który zaprojektował istotę każdego bytu ludzkiego i zlecił zadanie jej rozwijania $\mathrm{w}$ różnorakich kontaktach $\mathrm{z}$ bytami. Rozpoznając i rozwijając swoją istotę, człowiek przybliża się w jakiejś części do boskiej tajemnicy. Ukierunkowując się na inne byty i realizując w kontaktach z nimi swoją specyficzną istotę, znajduje jej spełnienie w samym Bogu ${ }^{47}$. W związku z tym, że osoba i Bóg jakoś się przenikają, Buber zauważy w swoim późniejszym dziele pt. Dwa typy wiary, że owym jedynym, prawdziwym kierunkiem jest sam Bóg ${ }^{48}$. Decyzja na rzecz dobra, którą człowiek podejmuje w spotkaniu z innymi stworzeniami, utożsamia się z obraniem kierunku ku Bogu ${ }^{49}$. Zdaniem Bubera bowiem każdy pojedynczy byt jest przebłyskiem ku Niemu ${ }^{50}$.

Max Brod porównywał dwa stany człowieka (dobro i zło) z żydowską nauką dotyczącą dwóch sposobów zachowania się Boga. Sprawuje On

46 Por. Ch. Schütz, Verborgenheit Gottes. Martin Bubers Werk - Eine Gesamtdarstellung, dz. cyt., s. 27-28.

47 Por. M. Buber, Bilder von Gut und Böse, dz. cyt., s. 648-650; tenże, Replies to My Critics, [w:] The Philosophy of Martin Buber, red. P. A. Schilpp, M. Friedman, London 1967, s. 721; tenże, Der Weg des Menschen nach der chassidischen Lehre, [w:] tegoż, Werke. Dritter Band. Schriften zum Chassidismus, München-Heidelberg 1963, s. 719-721.

48 Por. M. Buber, Zwei Glaubensweisen, dz. cyt., s. 696.

49 Por. M. Friedman, Die Grundlagen von Martin Bubers Ethik, [w:] Martin Buber, Hrsg. P. A. Schilpp, M. Friedman, Stuttgart 1963, s. 154.

50 Por. M. Buber, Ich und Du, dz. cyt., s. 128. 
albo karzący sąd, albo okazuje miłosierdzie. Bóg przechodzi z jednego stanu w drugi, ponieważ nie da się zamknąć w jednym z nich. Nie posiadają one jednak tej samej mocy. Miłosierdzie jest bowiem silniejsze. Podobnie u człowieka miara dobra jest większa niż miara zła, co wskazuje na jego podobieństwo do Boga ${ }^{51}$. Buber, zainspirowany tym żydowskim przekonaniem, wykazywał optymizm dotyczący możliwości pokonania zła. Miało ono bowiem dla niego charakter relatywny i było możliwe do przeobrażenia. Owszem, zło może stać się radykalne, ale my musimy się temu przeciwstawić. Człowiek nie odkupi wprawdzie swej egzystencji w pełni, ale winien próbować to czynić przez dialog ${ }^{52}$.

Jak jednak w ogóle może istnieć zło, kiedy istnieje dobry Bóg? Buber podkreślał, że natura człowieka nie jest zła. Może ona być tylko źle użyta. Gdy ktoś wchodzi na poziom zła radykalnego, to wcale nie znaczy to, że zło staje się absolutne, ale tylko wskazuje na bunt wobec tego, kim człowiek miał być. Dobro jest realizacją przez człowieka tego unikalnego celu, jaki został mu dany przez Stwórcę. Bóg pragnie, aby istota ludzka go osiągnęła, ale nie może się to wiązać $\mathrm{z}$ ograniczeniem wolności stworzeń. Bóg podejmuje tym samym ryzyko, że człowiek zamknie się na Niego i Jego plan ${ }^{53}$.

Odpowiedzią na problem istnienia zła i Boga jest zatem, mówiąc językiem Józefa Tischnera, teza, że człowiek został obdarzony „nieszczęsnym darem wolności”. W swojej kronice Buber zapisze: „Ale czym jest zło czynione przez Boga? Jest to moc czynienia tego, czego On nie chce. Gdyby jej nie stworzył, nikt nie mógłby $\mathrm{Mu}$ się przeciwstawić. Ale On chce, by Jego stworzenie mogło mu się przeciwstawić. Uczynił je wolnym. Dał mu moc takiego postępowania, jak gdyby nie było wszechmocy. Stworzenie nie tylko mniema, że może tak działać, lecz jest tak

${ }_{51}$ Por. M. Brod, Judentum und Christentum im Werk Martin Bubers, [w:] Martin Buber, Hrsg. P. A. Schilpp, M. Friedman, Stuttgart 1963, s. 325.

52 Por. M. Buber, Zur Darstellung des Chassidismus, [w:] tegoż, Werke. Dritter Band. Schriften zum Chassidismus, München-Heidelberg 1963, s. 986; Philosophical interrogations, dz. cyt., s. 111; M. L. Morgan, Martin Buber, cooperation and evil, „The Journal of the American Academy of Religion" $1990 \mathrm{nr}$ 1, s. 105, 107.

${ }_{53}$ Por. M. Friedman, Martin Buber's new view of evil, dz. cyt., s. 246. 
naprawdę, ma taką moc. Oto prawdziwy sens tego, na co wskazuje się, mówiąc, że Otchłań ograniczyła się do świata. Nauczyliśmy się, że uczyniła ona w sobie miejsce dla świata, ale najważniejsze jest, że ona wydzieliła ze swej wszechmocy prawdziwą moc, przydzieloną każdemu człowiekowi; i że jest ta prawdziwa moc boża przejawia się w możliwości buntu przeciwko Bogu. A bez tej prawdziwej mocy, która została przydzielona człowiekowi, nie ma też dobra, ponieważ dobro jest tylko wówczas, gdy jest czynione z całą tą mocą. Czym jest dobro, które Bóg stwarza? Jest zwróceniem się ku Niemu [...]"54.

\section{Zakończenie}

Powyższe analizy były próbą prezentacji koncepcji zła, której autorem jest Martin Buber. Zło rozumie on jako brak ukierunkowania swego życia i egzystowanie wyłącznie na poziomie wielu możliwości stwarzanych przez świat. Dopiero poprzez skierowanie się ku konkretnej rzeczy lub osobie i odniesienie jej do Boga jako jej Stwórcy zostanie nadana życiu właściwa orientacja, a tym samym człowiek odwróci się od zła w stronę dobra. Widzimy więc, iż koncepcja zła i dobra jest ściśle związana z Buberowskim pojęciem Boga. Zło wiązałoby się z odwróceniem się od boskiego bytu i pogrążeniem w świecie, dobro natomiast ze skierowaniem się ku Bogu, który prowadzi dialog z człowiekiem poprzez byty stworzone.

Powyższa koncepcja jest wynikiem odczytania oraz interpretacji treści zawartych w mitach perskich i biblijnych. Mit jest dla żydowskiego myśliciela świadectwem spotkania z Absolutem, a przez to ważnym narzędziem w odkryciu prawdy o ludzkiej egzystencji. Ponowne odczytanie mitów biblijnych było okazją, aby z jednej strony odkryć prawdę o znaczonym przeciwieństwami życiu człowieka, z drugiej natomiast usłyszeć wezwanie do nadania mu właściwego kierunku. Mity staroperskie dały natomiast opis człowieka jako istoty tkwiącej w kłamstwie egzystencjalnym, polegającym na udawaniu kogoś innego, niż jest się 
w rzeczywistości i jednocześnie niemogącej lub niechcącej podjąć decyzji odnośnie do zmiany tego stanu rzeczy. Relektura podań starożytnych prowadziła Bubera do ich reinterpretacji i wykrystalizowania się filozoficznego ujęcia zła moralnego i powiązanego z nim pojęcia dobra. Doświadczenie zła przez człowieka polega na życiu w chaosie możliwości, czyli różnych sposobów bycia i postępowania. Sytuacja taka powoduje w nim jednak niepokój i wewnętrzne napięcie. Możliwe są z niej dwie drogi wyjścia. Człowiek może albo tkwić w tym stanie (zło radykalne), albo podjąć decyzję odnośnie do ukierunkowania swego życia i postępowania na Boga (dobro).

Powyższa próba zaprezentowania koncepcji Bubera wiązała się $\mathrm{z}$ pewnymi trudnościami. Jedną $\mathrm{z}$ nich jest przenikanie się $\mathrm{w}$ jego twórczości tez ściśle filozoficznych z religijnymi. Nie da się zresztą właściwie zrozumieć jego filozofii bez znajomości, przynajmniej częściowej, jej religijnego zaplecza. Istotnym problemem jest także niejasność i metaforyczność wielu twierdzeń. Buber nie miał nigdy zamiaru tworzenia uporządkowanego systemu myślowego. Dlatego też nie dbał o ścisłość i porządek swoich wypowiedzi. Mamy zatem u niego do czynienia z licznymi porównaniami, przenośniami i wypowiedziami sprawiającymi w pierwszym momencie wrażenie chaosu.

Wiele też kwestii w myśli Bubera wymaga dalszej, bardziej szczegółowej analizy. Sam problem zła i dobra domaga się dalszych badań. Wydają się one bowiem być „danymi antropologicznymi”, a więc jakąś formą fenomenów. W związku z tym jawi się pytanie, w jakim sensie można mówić o ich realności. Inną kwestią godną uwagi jest niewątpliwie pojęcie Boga i związany z nim panenteizm. Wydaje się, że należałoby się bliżej przyjrzeć Buberowskiej etyce, znaczonej z jednej strony silnymi związkami z religią, z drugiej natomiast sytuacjonizmem.

Pomimo owych trudności i niedomówień można chyba zgodzić się z zasadniczą intuicją Bubera zaprezentowaną w powyższych rozważaniach. Odnosi się ona do człowieka posiadającego poczucie bezsensu swego życia (rozbicia) lub jego sensowności (ukierunkowania). W tym pierwszym przypadku jest on wezwany do podjęcia odważnej decyzji zmierzającej do nadania sensu swej egzystencji poprzez określenie jej 
konkretnego celu i odważne zmierzanie ku niemu. Buber jednak zdaje się iść krok dalej. Sugeruje on mianowicie, że prawdziwego sensu naszemu życiu nie może nadać żaden cel lub byt ziemski. Jedynie bowiem Istota Transcendentna może zapewnić człowiekowi spełnienie jego egzystencji.

\section{Bibliografia}

Buber M., Bilder von Gut und Böse, [w:] tegoż, Werke. Erster Band. Schriften zur Philosophie, München-Heidelberg 1962, s. 605-650.

Buber M., Die chassidische Botschaft, [w:] tegoż, Werke. Dritter Band. Schriften zum Chassidismus, München-Heidelberg 1963, s. 739-894.

Buber M., Gog und Magog. Eine Chronik, [w:] tegoż, Werke. Dritter Band. Schriften zum Chassidismus, München-Heidelberg 1963, s. 999-1261.

Buber M., Ich und Du, [w:] tegoż, Werke. Erster Band. Schriften zur Philosophie, München-Heidelberg 1962, s. 77-170.

Buber M., Zwei Glaubensweisen, [w:] tegoż, Werke. Erster Band. Schriften zur Philosophie, München-Heidelberg 1962, s. 651-782.

Friedman M., Die Grundlagen von Martin Bubers Ethik, [w:] Martin Buber, Hrsg. P. A. Schilpp, M. Friedman, Stuttgart 1963, s. 153-179.

Friedman M., Martin Buber. The life of dialogue, Chicago 1955.

Friedman M., Martin Buber's new view of evil, „Judaism” 1953 nr 2/3, s. 239-246.

Morgan M. L., Martin Buber, cooperation and evil, „The Journal of the American Academy of Religion" 1990 nr 1, s. 99-109.

Philosophical interrogations, ed. S. i B. Rome, New York 1964.

Rogers C., Aneks (Dyskusja: C. Rogers, M. Buber), „Znak” 1968 nr 11/12, s. 1531-1538.

Roy O., Martin Buber. Der Wanderer und der Weg, Heildelberg 1968.

Schütz Ch., Verborgenheit Gottes. Martin Bubers Werk - Eine Gesamtdarstellung, ZürichEinsiedeln-Köln 1975. 
